\title{
Apologies as 'shame management': the politics of remorse in the aftermath of historical institutional abuse
}

\author{
Anne-Marie McAlinden ${ }^{\star \dagger}$ (DD \\ School of Law, Queen's University Belfast, Northern Ireland \\ *Author email: a.mcalinden@qub.ac.uk
}

(Accepted 8 June 2021)

\begin{abstract}
This paper examines the role of apology as a vehicle for shame management in the aftermath of historical institutional abuse (HIA). It draws on extensive fieldwork in Ireland, North and South, including: archival research on public apologies; focus groups with members of the public and with victims; and semistructured interviews with key stakeholders. It focuses on the complexities of apology in managing 'shame' and 'self-blame' for those constituencies affected by HIA - survivors, apologisers, institutions and wider society. Drawing on the notions of 'shame' and 'shame management', it proposes an interdependent model in order to better understand the function and meaning of apology in such contexts. In addressing the multi-layered relational dimensions of shame surrounding HIA, apology is presented as a potential means of invoking: (a) truth for victims; (b) accountability of offenders; (c) leadership of institutions; and (d) the re-imagination of national identity. The paper concludes by examining the additional performative aspects of shaming and the emotional expression of remorse in establishing proximity to historical wrongdoing.
\end{abstract}

Keywords: apologies; institutional abuse; shame; self-blame; performance; emotion

\section{Introduction}

The Magdalene Laundries have cast a long shadow over Irish life over our sense of who we are... What we address today is how you took this country's terrible 'secret' and made it your own... But from this moment on you need carry it no more. Because today we take it back...The Magdalene Women might have been told that they were washing away a wrong or a sin but we know now and to our shame they were only ever scrubbing away our nation's shadow... For we saw difference as something to be feared and hidden rather than embraced and celebrated... The women are and always were wholly blameless... This is a national shame, for which I again say, I am deeply sorry and offer my full and heartfelt apologies. ${ }^{1}$

To confront the dark and shameful reality which is detailed in this report we must acknowledge it as part of our national history... And so, on behalf of the Government, the State and its citizens, I apologise for the profound generational wrong visited upon Irish mothers and their children

\footnotetext{
${ }^{\dagger}$ The author would like to thank Professor Kieran McEvoy, Professor Shadd Maruna, Dr Anna Bryson (as three of the project team members) and Dr Luke Moffett, as well as the two anonymous reviewers, for their helpful comments on earlier versions of the paper. I would also like to thank Dr Anna Bryson, Dr Lauren Dempster, Dr Kevin Hearty and Dr Ashleigh McFeeters for their excellent research assistance. Any errors are my own.

${ }^{1}$ E Kenny Dáil Debates, 19 February 2013. State apology following publication of the McAleese Report (2013).

(c) The Author(s), 2021. Published by Cambridge University Press. This is an Open Access article, distributed under the terms of the Creative Commons Attribution licence (http://creativecommons.org/licenses/by/4.0/), which permits unrestricted re-use, distribution, and reproduction in any medium, provided the original work is properly cited.
} 
who ended up in a Mother and Baby Home... I apologise for the shame and stigma which they were subjected to and which, for some, remains a burden to this day. In apologising, I want to emphasise that each of you were in an institution because of the wrongs of others. Each of you is blameless, each of you did nothing wrong and has nothing to be ashamed of. ${ }^{2}$

Recent decades have been characterised as 'an age of apology', ${ }^{3}$ with scholars describing the existence of 'contrition chic' ${ }^{4}$ and 'sorry justice'. ${ }^{5}$ Within the political arena, examples of state apologies for historical wrongdoing abound with Bill Clinton (1998), Kevin Rudd (2008), David Cameron (2010) and Justin Trudeau (2017) all having apologised on behalf of their respective nations for slavery, 'the Stolen Generations' of aboriginal children, 'Bloody Sunday' ${ }^{6}$ and abuses of indigenous children in church-run residential schools. More recently, we have witnessed a degree of cultural saturation with apologies as a result of the global \#MeToo! and \#TimesUp! movements. ${ }^{7}$ This phenomenon of 'over apologising' by public or political figures via the excessive use of public apology in cases of highly publicised wrongdoing has given rise to broader questions concerning the meaningfulness of apology or 'when is an apology not an apology. ${ }^{8}$ Notwithstanding these understandable misgivings, fulsome apologies, choreographed and delivered in conjunction with affected constituencies, may yet provide an effective means for states and organisations to engage with victimised communities and address the legacy of the past. ${ }^{9}$ Drawing on the intersecting literatures on 'apologies' and 'shame', this paper examines the potential of predominantly public apologies to address the complexities of shame surrounding historical institutional abuse and engage the multiple constituencies impacted by the legacy of HIA - victims/survivors, perpetrators, the institutions of Church and State and wider society - at the interpersonal, institutional and societal levels. While the empirical work is focused on Ireland, both Northern Ireland (NI) and the Republic of Ireland (RoI), the findings have resonance for other societies coming to terms with past abuses.

To begin, it is useful to define terms, including what is meant by 'apology' and 'historical institutional abuse'. There is an expansive interdisciplinary literature on 'apology' - traversing law, ${ }^{10}$ political science, ${ }^{11}$

\footnotetext{
${ }^{2}$ M Martin Dáil Debates, 13 January 2021. State apology following publication of the Final Report of the Commission of Investigation into Mother and Baby Homes (2021).

${ }^{3} \mathrm{M}$ Gibney et al (eds) The Age of Apology: Facing up to the Past (University of Pennsylvania Press, 2008).

${ }^{4} \mathrm{~W}$ Shapiro 'Mama mia, that's a mea culpa', Time Magazine, 30 June 1997.

${ }^{5}$ NJ Blecher 'Sorry justice: apology in Australian family group conferencing' (2011) 18 Psychiatry, Psychology and Law 95.

${ }^{6}$ BBloody Sunday' refers to the massacre on Sunday 30 January 1972 in the Bogside area of Derry, Northern Ireland, when British soldiers shot dead 13 and wounded a further 15 unarmed civilians during a civil rights march against internment.

${ }^{7}$ See eg G Nigro et al 'Apologies in the \#MeToo moment' (2020) 9 Psychology of Popular Media 403. It has also been accompanied by 'apology aversion' by public figures - such as former US President Donald Trump - and a reluctance to publicly apologise for alleged wrongdoing: M Garber 'Sorry, not sorry: why public figures stopped apologizing', The Atlantic, December 2019.

${ }^{8} \mathrm{R}$ Jeffery 'When is an apology not an apology? Contrition chic and Japan's (un)apologetic politics' (2011) 65 Australian Journal of International Affairs 607.

${ }^{9}$ There are several notable examples of where an official apology for historical abuses was constructed and delivered by the state in conjunction with victim groups. See, for example, the first official apology by then Taoiseach (Irish Prime Minister), Bertie Ahern, on behalf of the Irish State to those abused as children in residential institutions: 11 May 1999, press conference, Dublin; see also the apology by Canadian Prime Minister, Justin Trudeau, on behalf of the Government of Canada for historical abuses of indigenous children in residential schools in Newfoundland and Labrador: 24 November 2014, ceremony, Happy Valley-Goose Bay, Newfoundland.

${ }^{10}$ See eg P Vines 'The power of apology: mercy, forgiveness or corrective justice in the civil liability arena' (2007) 1 Public Space: The Journal of Law \& Social Justice 1; N Smith Justice through Apologies: Remorse, Reform, and Punishment (Cambridge: Cambridge University Press, 2014).

${ }^{11}$ See eg M Cunningham 'Saying sorry: the politics of apology' (1999) 70 The Political Quarterly 285; M Nobles The Politics of Official Apologies (Cambridge: Cambridge University Press, 2008).
} 
management and communication studies, ${ }^{12}$ history, ${ }^{13}$ sociology, ${ }^{14}$ anthropology, ${ }^{15}$ and social psych$\operatorname{ology}^{16}$ which is drawn upon below. Perhaps unsurprisingly, however, given the diversity of this disciplinary terrain, there is little consensus on a precise conceptual definition. Nonetheless, scholars generally agree that an apology involves specific acknowledgement of wrongdoing and an unequivocal expression of regret. ${ }^{17}$ In addition, many theorists contend that a future focus, namely the promise of nonrepetition and the offer of corrective action (via, for example, compensation or policy reform), is equally important in addressing past wrongs. ${ }^{18}$

The term HIA broadly refers to three interrelated categories: past abuses of women and children in residential care, ${ }^{19}$ including care homes, industrial schools, mother and baby institutions and 'Magdalen laundries'; ${ }^{20}$ past abuses by members of religious organisations (also known as 'clerical sexual abuse'); ${ }^{21}$ and the forced removal of children from their families where many suffered abuse and neglect whilst in institutional care. ${ }^{22}$ In tandem with the focus in Northern Ireland and the Republic of Ireland, the term HIA for present purposes primarily encompasses the first two categories and is taken to mean past abuses of children and women within religious contexts including sexual abuse, as well as physical and emotional abuse and neglect.

The limited body of empirical work on apology for historical injustices has been undertaken from within a predominantly psychological framework and has tended to concentrate on: content analysis of government apologies; ${ }^{23}$ the perceptions of such apologies by victimised or non-victimised communities; ${ }^{24}$ or the extent to which they elicit forgiveness or positive intergroup relations. ${ }^{25}$ However, this literature tends to be very state-centric and there is a distinct lack of empirical research on apologies within the domain of HIA. This paper addresses these gaps within the literature by focusing on apologies by non-state as well as state actors and by incorporating primary research on HIA, including the perspectives of apologising institutions as well as victims/survivors. It draws on extensive empirical

\footnotetext{
${ }^{12}$ See eg KM Hearit Management by Apology: Corporate Responses to Allegations of Wrongdoing (Lawrence Erlbaum Associates, 2006); WL Benoit Accounts, Excuses, and Apologies: Image Repair Theory and Research (SUNY Press, $2^{\text {nd }}$ edn, 2015).

${ }^{13}$ See eg R Weyeneth 'The power of apology and the process of historical reconciliation' (2001) 23 The Public Historian 9; MR Marrus 'Official apologies and the quest for historical justice' (2007) 6 Journal of Human Rights 75.

${ }^{14}$ See eg E Goffman Relations in Public: Microstudies of the Public Order (Basic Books, 1971); N Tavuchis Mea Culpa: A Sociology of Apology and Reconciliation (Stanford University Press, 1991).

${ }^{15}$ See eg J Borneman 'Can public apologies contribute to place? An argument for retribution' (1999) 17 Anthropology of East Europe Review; MR Trouillot 'Abortive rituals: historical apologies in the global era' (2000) 2 Interventions: International Journal of Postcolonial Studies 171.

${ }^{16}$ See eg MJA Wohl et al 'Why group apologies succeed and fail: intergroup forgiveness and the role of primary and secondary emotions' (2012) 102 Journal of Personality and Social Psychology 306.

${ }^{17}$ See eg Tavuchis, above n 14; A Lazare On Apology (Oxford: Oxford University Press, 2004).

${ }^{18}$ See eg S Alter Apologizing for Serious Wrongdoing: Social, Psychological and Legal Considerations, Final Report (Law Commission of Canada, 1999); D Slocum et al 'An emerging theory of apology' (2011) 63 Australian Journal of Psychology 83.

${ }^{19}$ See eg K Daly Redressing Institutional Abuse of Children (Palgrave Macmillan, 2014).

${ }^{20}$ 'Magdalen laundries' were institutions run predominantly by the Catholic Church on behalf of the State for 'fallen women' and operated in Ireland from the eighteenth century to the late twentieth century.

${ }^{21}$ See eg M Keenan Child Sexual Abuse and the Catholic Church: Gender, Power, and Organizational Culture (Oxford: Oxford University Press, 2011).

${ }^{22}$ See eg D Cuthbert and M Quartly 'Forced child removal and the politics of national apologies in Australia' (2013) 37 American Indian Quarterly 178.

${ }^{23}$ See eg CW Blatz et al 'Government apologies for historical injustices' (2009) 30 Political Psychology 219.

${ }^{24}$ See eg CW Blatz et al 'Official public apology effects on victim group members' evaluations of the perpetrator group' (2014) 46 Canadian Journal of Behavioural Science 337; M Cárdenas et al 'Predictors of support toward transitional justice process in Chilean general population sample' (2017) 16 Journal of Community and Applied Social Psychology 67.

${ }^{25}$ See eg Wohl et al, above $\mathrm{n} \mathrm{16}$; A Allan et al 'Exploration of the association between apology and forgiveness amongst victims of human rights violations' (2006) 24 Behavioral Sciences \& the Law 87; RR Steele and CW Blatz 'Faith in the just behavior of the government: intergroup apologies and apology elaboration' (2014) 2 Journal of Social and Political Psychology 268.
} 
data conducted for the wider Apologies, Abuses and Dealing with the Past project, in the form of a specially compiled archive of public apologies for HIA over the last three decades, focus groups with members of the public and with victims and semi-structured interviews with key stakeholders in Ireland, both in NI and the RoI. ${ }^{26}$

Based on insights from the theoretical literature and the primary data, the paper proposes an interrelated model of apology in order to better understand the function and meaning of remorse in such contexts. It is contended that 'shame' in the aftermath of HIA is effectively managed when apology is optimised to facilitate: (a) 'truth' for victims; (b) accountability of offenders; (c) leadership of institutions; and (d) the re-imagination of national identity. Each of these components is necessary and contingent for the effective individual, organisational and societal 'coming to terms' with an abusive past. In this sense, apology is presented not only in predominantly relational terms but also in an expressive and performative sense in addressing the multi-dimensions of shame (interpersonal, organisational and societal) surrounding HIA.

The structure of the paper is as follows: Part 1 begins by providing a critical overview of the core themes from the literature on apologies, shame and dealing with the past. Part 2 briefly outlines the triangulated research methodology utilised in the study. Part 3 delineates a model of shame management and its four interdependent elements, drawing on the findings from the empirical research. Finally, having considered the relational dimensions, the concluding section considers the performance of shame and how the emotional spectacle of apology is optimally choreographed and delivered in HIA contexts and more broadly.

\section{Apologies, shame and dealing with the past}

This section highlights the centrality of shame to the legacy of HIA in Ireland, and draws out the principal themes from the literature on apologies as redress for wrongdoing and in particular the notions of shaming and shame management.

\section{(a) Historical institutional abuse and the legacy of shame in Ireland}

As Hogan emphasises, historical institutional abuses in Ireland were underpinned by 'a shame-industrial complex'. ${ }^{27}$ Consistent with classic anthropological accounts of 'shame cultures' ${ }^{28}$ in the Ireland of the previous century, 'shame' was the fulcrum of the moral governance of society. A culture of 'chronic' or 'toxic shame ${ }^{29}$ was integral to the Catholic faith and played out through religious rituals such as the sacrament of reconciliation (or 'confession') whereby a 'penitent' confesses their sins to a priest. The virtues of chastity, modesty, piety and sobriety were in turn reinforced in Irish homes, schools and communities and directed towards women and children in particular. ${ }^{30}$ The cultural prevalence of shame was also scaffolded by the deeply enmeshed relationship of Church and State. The Catholic Church had a de facto 'moral monopoly'31 over issues concerning sex and sexuality - including censorship, contraception, abortion and sex outside marriage - in the domains of health, education, social welfare and family life. ${ }^{32}$ Moreover, institutions such as industrial

\footnotetext{
${ }^{26}$ ESRC Grant Reference ES/N010825/1. See https://apologies-abuses-past.org.uk/.

${ }^{27} \mathrm{C}$ Hogan Republic of Shame: Stories from Ireland's Institutions for 'Fallen Women' (Penguin, 2019), inside cover, unpaginated.

${ }^{28}$ See eg R Benedict The Chrysanthemum and the Sword: Patterns of Japanese Culture (Routledge and Kegan Paul, 1946).

${ }^{29} \mathrm{CJ}$ Park 'Chronic shame: a perspective integrating religion and spirituality' (2016) 3 Journal of Religion \& Spirituality in Social Work: Social Thought 354.

${ }^{30} \mathrm{G}$ Meaney Sex and Nation Women in Irish Culture and Politics (Attic Press, 1991).

${ }^{31}$ T Inglis Moral Monopoly: The Rise and Fall of the Catholic Church in Modern Ireland (UCD Press, 1998).

${ }^{32}$ There is a complex constitutional picture as regards the evolution of Church-State relations in Ireland which operated predominantly within a political rather than legal/constitutional framework. See eg D Keogh and A McCarthy The Making of the Irish Constitution, 1937 (Mercier Press, 2007).
} 
schools, 'Magdalen laundries' and mother and baby homes were run by the Church on behalf of the Irish State.

A 'politics of shame ${ }^{33}$ thus became integral to both the self-image of the Church and to national identity wherein the violation of moral norms was regarded as an assault on 'mother church' and 'mother Ireland'. This rigid moral code was bolstered by the complicity of Irish citizens who were culpable as 'bystanders' in committing family members to institutions or in failing to challenge the status quo. $^{34}$ The principal effects of the inculcation of the culture of shame were the silencing of victims and a societal and political reluctance to openly challenge the institutional Church for decades. Similarly, in Northern Ireland, the cultural pervasiveness of a conservative morality and shame around sex and sexuality has meant that these topics are precluded from even contemporary public and official discourses. $^{35}$

In addition, there was an acute gendered shame attached to pregnancy outside of marriage as it belied the notion of Ireland as a morally pure nation. As Earner-Byrne highlights, unmarried mothers were seen as 'a moral contagion,' removed from Irish society so that the visible manifestation of their shame and sin of extra-marital sex would not contaminate others. ${ }^{36}$ Certainly, within such a patriarchal society, a toxic masculinity dominated public and official discourses on shame, so that the social opprobrium and institutional punishment of unmarried mothers was deemed culturally acceptable but not extended to unmarried fathers in the same way. However, women and children were incarcerated, due not only to perceived sexual transgression but to a range of other intersectional circumstances considered shameful including poverty, class, disability or minor criminality. ${ }^{37}$ There is also some evidence of the hierarchical nature of such shaming punishments, as middle-class women and girls were often committed to a better class of home or were able to get 'the boat to England'. ${ }^{38}$ All of these interdependent variables undermined the creation of Ireland as 'the gage and emblem'39 of an emerging modern, progressive nation, distinct from Great Britain, in the early part of the twentieth century.

Shaming practices also became a systemic part of the 'architecture of containment ${ }^{\text {'40 }}$ where they were used by religious figures in positions of authority to both punish and purge the stigmatised identities of women and children within the institutions. Adult survivors of residential care homes and industrial schools in particular have reflected on the use of numbers or pseudonyms, head shaving and severe corporal punishment, often dispensed openly in front of their peers, as a means of public shaming, dehumanisation and removing any vestiges of their former identity. ${ }^{41}$ For many victimsurvivors, the effects of such shaming practices and their experiences of institutionalisation have been prolonged, continuing to impact their lives. ${ }^{42}$ Addressing these complex and intersecting dimensions of 'shame' - traversing the processes of victimisation, the institutional and cultural frameworks

\footnotetext{
${ }^{33} \mathrm{C}$ Fischer 'Gender, nation, and the politics of shame: Magdalen laundries and the institutionalization of feminine transgression in modern Ireland' (2016) 41 Signs: Journal of Women in Culture and Society 821.

${ }^{34}$ E O'Sullivan and I O’Donnell (eds) Coercive Confinement in Ireland: Patients, Prisoners and Penitents (Manchester University Press, 2012).

${ }^{35} \mathrm{G}$ Ellison 'Criminalizing the payment for sex in Northern Ireland: sketching the contours of a moral panic' (2017) 57 British Journal of Criminology 194.

${ }^{36}$ L Earner-Byrne 'Moral repatriation: the response to Irish unmarried mothers in Britain, 1920s-1960s' in P Duffy (ed) To and from Ireland: Planned Migration Schemes, 1600-2000 (Geography Publications, 2004).

${ }^{37} \mathrm{M}$ Enright and S Ring 'State legal responses to historical institutional abuse: shame, sovereignty and epistemic injustice' (2020) 55 Éire-Ireland 68.

${ }^{38} \mathrm{~L}$ Earner-Byrne 'The boat to England: an analysis of the official reactions to the emigration of single expectant Irishwomen to Britain, 1922-1972' (2003) 3 Irish Economic and Social History 52.

${ }^{39} \mathrm{~B}$ Anderson Imagined Communities: Reflections on the Origin and Spread of Nationalism (Verso Books, 1983) p 7.

${ }^{40} \mathrm{JM}$ Smith Ireland's Magdalen Laundries and the Nation's Architecture of Containment (University of Notre Dame Press, 2007).

${ }^{41}$ See eg Report of the Commission to Inquire into Child Abuse (Chair: Judge Séan Ryan) at http://www.childabusecommission. ie/ (2009), vol I, chs 7 and 8; vol II, ch 7.

${ }^{42} \mathrm{M}$ O'Rourke 'Prolonged impunity as a continuing situation of torture or ill-treatment? Applying a dignity lens to so-called "historical” cases' (2019) 66 Netherlands International Law Review 101 at 125, 134.
} 
underpinned by Church and State and the complicity of Irish citizens - thus becomes an integral aspect of 'apology' in the aftermath of HIA in Ireland at the interpersonal, institutional and societal levels.

\section{(b) Apologies as redress for wrongdoing}

From the sociological literature, Goffman's much-cited framing of apologies underlines their corrective utility: 'gestures through which an individual splits himself in two parts, the part that is guilty of an offence and the part that disassociates itself from the delict and affirms a belief in the offended rule'. ${ }^{4}$ What this interpretation makes clear is not only that the meaning and value of apologies lies in the interaction between the speaker and hearer of the apology, but that acknowledging and managing the shame of wrongdoing is an integral part of the remedial function of apology. In this respect, the literature conceives of apology as a 'speech act' ${ }^{44}$ - a verbal utterance that serves as a purposive action. An apology may restore dignity and alleviate psychological harm for both victims and perpetrators, facilitating emotional and moral rebalance at the individual and collective levels. ${ }^{45}$ At the same time, there is also a growing conceptualisation of the non-verbal, performative aspects of apology, ${ }^{46}$ including the emotional expression of shame or regret. This critical tension underlines the fact that how the words of remorse are expressed may be just as crucial as the actual words themselves.

Apologies as a means of redress have long been a mainstay of justice responses and are pertinent to at least four broad areas of scholarship concerning addressing past harms. First, within formal legal settings, apologies have featured in both criminal and civil cases as part outcomes, or to facilitate early settlement or mitigate legal action completely. ${ }^{47}$ For some victims, including victims of HIA, emotional or symbolic reparation via acknowledgement of wrongdoing is often more important than material reparation. ${ }^{48}$ Western legal culture, however, discourages apology as an acceptance of blame or admission of responsibility due to fears of legal or financial liability. ${ }^{49}$ As discussed further, this can often result in the 'safe ${ }^{50}$ or 'pseudo-apology', ${ }^{51}$ expressing sympathy for wrongdoing but avoiding any admission of responsibility.

Secondly, within public law discourses, official apologies are offered or elicited in the aftermath of high-profile tragedies or political crises as part of 'image repair', where organisations seek to engage both individual victims as well as wider society. ${ }^{52}$ Official apologies for HIA are usually given at the culmination of inquiry processes, such as the publication of inquiry reports, ${ }^{53}$ although they can also

\footnotetext{
${ }^{43}$ Goffman, above n 14, p 143.

${ }^{44} \mathrm{JL}$ Austin How to Do Things with Words (Harvard University Press, 2nd edn, 1962).

${ }^{45}$ J Cohen 'Legislating apology: the pros and cons' (2002) 70 University of Cincinnati Law Review 824.

${ }^{46}$ See eg D Celermajer The Sins of the Nation and the Ritual of Apologies (Cambridge: Cambridge University Press, 2009); EK Wilson and R Bleiker 'Performing political apologies' in E Resende and D Budryte (eds) Memory and Trauma in International Relations (Routledge, 2013).

${ }^{47}$ See esp N Smith Justice through Apologies: Remorse, Reform, and Punishment (Cambridge: Cambridge University Press, 2014).

${ }^{48} \mathrm{~N}$ Roht-Arriaza 'Reparations, decisions and dilemmas' (2004) 27 Hastings International and Comparative Law Review 157.

${ }^{49}$ JK Robbennolt 'Apologies and legal settlement: an empirical examination' (2003) 102 Michigan Law Review 460.

${ }^{50} \mathrm{~L}$ Taft 'Apology subverted: the commodification of apology' (2000) 109 The Yale Law Journal 1135.

${ }^{51}$ Lazare, above n 17, p 9.

${ }^{52}$ Benoit, above n 12; see also T Barth 'Crisis management in the Catholic Church: lessons for public administrators' (2010) 70 Public Administration Review 780.

${ }^{53}$ See eg in the Republic of Ireland: Report of the Commission to Inquire into Child Abuse, above $\mathrm{n} 41$; Report by the Commission of Investigation into the Catholic Archdiocese of Dublin (Chair: Judge Yvonne Murphy) (Department of Justice, 2009); Report of the Inter-Departmental Committee to Establish Facts of State Involvement with the Magdalen Laundries (Chair: Senator Martin McAleese) (Department of Justice, 2013); and Final Report of the Commission of Investigation into Mother and Baby Homes (Department of Children, Equality, Disability, Integration and Youth, 2021); and in Northern Ireland: Report of the Historical Institutional Abuse Inquiry (Chair: Sir Anthony Hart, 2017) at https:// www.hiainquiry.org/historical-institutional-abuse-inquiry-report-chapters.
} 
accompany the official announcement or commencement of these. ${ }^{54}$ Such apologies are a potential means of acknowledging individual and collective wrongdoing, validating the suffering of victims, and furthering individual and societal healing by marking a symbolic break from the past. However, as discussed further, questions have also emerged within public discourse surrounding 'apology polit$\mathrm{ics}^{55}$ and their adequacy, sincerity and intent.

Thirdly, official apologies have also featured as part of symbolic reparations within transitional justice (TJ) discourses. The significance of the 'transitional apology ${ }^{56}$ - while typically deployed as part of a broader package of measures encompassing prosecutions, truth recovery, and institutional reform ${ }^{57}$ lies in its 'transformative potential'. ${ }^{58}$ That is, apologies can represent a break with past abuses and a commitment to social, political or institutional change. Traditionally conceived of as a framework within post-conflict or post-authoritarian settings, TJ mechanisms have also been extended to settled democracies, ${ }^{59}$ including within the realm of HIA, as a means of repairing societal relationships, as well as those between survivors and perpetrators, and of addressing individual as well as collective harms. ${ }^{60}$ Australia, ${ }^{61}$ Canada $^{62}$ and Ireland, ${ }^{63}$ for example, have used a mixture of apology, reparation, compensation and truth commission in response to clerical sexual abuse as well as institutional abuses against indigenous peoples. In this vein, the 'exceptional' nature of TJ is thought to be over-stated ${ }^{64}$ and the explicit use of TJ frameworks to deal with the legacy of HIA is testament to its resonance for transitions from abusive regimes in consolidated democracies. ${ }^{65}$ However, the specific features which characterise TJ processes within settled democracies - such as the blurred break with the past and the mixture of transitional and 'ordinary' justice ${ }^{66}$ - arguably place greater onus on apology as a means of symbolic reparation in such settings.

Fourth, and most relevant for present purposes, restorative settings, such as mediation, are thought to offer a 'safe space' for apologies ${ }^{67}$ and a means of repairing the emotional dimension of 'harm' ${ }^{68}$ For some restorative justice (RJ) scholars, empathy, remorse or guilt are the key emotional variables, ${ }^{69}$

\footnotetext{
${ }^{54}$ See eg the first official apology by then Taoiseach, Bertie Ahern, on behalf of the Irish state, above $\mathrm{n} 9$, while also announcing the setting up of the Commission to Inquire into Child Abuse and the Redress Board.

${ }^{55}$ Cuthbert and Quartly, above n 22.

${ }^{56} \mathrm{R}$ Teitel 'The transitional apology' in E Barkan and A Karn (eds) Taking Wrongs Seriously: Apologies and Reconciliation (Stanford University Press, 2006) pp 101-114.

${ }^{57}$ RG Teitel, Transitional Justice (Oxford: Oxford University Press, 2000).

${ }^{58} \mathrm{P}$ Gready and S Robins 'From transitional to transformative justice: a new agenda for practice' (2014) 8 International Journal of Transitional Justice 339.

${ }^{59} \mathrm{~S}$ Winter 'Towards a unified theory of transitional justice' (2013) 7 International Journal of Transitional Justice 224.

${ }^{60} J$ Gallen 'Jesus wept: the Roman Catholic Church, child sexual abuse and transitional justice' (2016) 10 International Journal of Transitional Justice 332.

${ }^{61}$ See eg comparisons of Australia and Ireland: A-M McAlinden and B Naylor 'Reframing public inquiries as procedural justice for victims of institutional child abuse: towards a hybrid model of justice' (2016) 38 Sydney Law Review 277; K Gleeson and S Ring 'Confronting the past and changing the future? Public inquiries into institutional child abuse, Ireland and Australia' (2021) 29 Griffith Law Review 109.

${ }^{62} \mathrm{JJ}$ Llewellyn 'Dealing with the legacy of native residential school abuse in Canada: litigation, ADR, and restorative justice' (2002) 52 University of Toronto Law Journal 253. See also comparisons of Canada and Australia: K Daly Redressing Institutional Abuse of Children (Palgrave Macmillan, 2014).

${ }^{63} \mathrm{~A}-\mathrm{M}$ McAlinden 'An inconvenient truth: barriers to truth recovery in the aftermath of institutional child abuse in Ireland' (2013) Legal Studies 189.

${ }^{64}$ EA Posner and A Vermeule 'Transitional justice as ordinary justice' (2004) 117 Harvard Law Review 761.

${ }^{65} \mathrm{~K}$ McEvoy et al 'Criminology and transitional justice' in A Liebling et al (eds) The Oxford Handbook of Criminology (Oxford: Oxford University Press, 2017) pp 394-396.

${ }^{66}$ A Álvarez Berastegi 'Transitional justice in settled democracies: Northern Ireland and the Basque country in comparative perspective' (2017) 10 Critical Studies on Terrorism 542.

${ }^{67} \mathrm{CD}$ Schneider 'What it means to be sorry: the power of apology in mediation' (2000) 3 Mediation Quarterly 265.

${ }^{68} \mathrm{H}$ Strang 'Justice for victims of young offenders: the centrality of emotional harm and restoration' in A Morris and G Maxwell (eds) Restorative Justice for Juveniles: Conferencing, Mediation and Circles (Oxford: Hart Publishing, 2001).

${ }^{69}$ See eg B Van Stokkom 'Moral emotions in restorative justice conferences: managing shame, designing empathy' (2002) 6 Theoretical Criminology 339.
} 
whereas for others, 'shame' emerges as the 'master emotion' within restorative discourses. ${ }^{70}$ 'Shame' in this context generally refers to a negative emotion, caused by the consciousness of serious wrongdoing, often leading to negative internal self-evaluation and self-blame. ${ }^{71}$ As Park highlights, shame is fundamentally a relative concept reinforced by 'relational interactions' ${ }^{72}$ In this sense, it is important to acknowledge the nuances and complexities of 'shame' within the context of HIA, in terms of the multiple sources of shame (such as families, culture and religion), ${ }^{73}$ the overlap with other moral emotions such as guilt ${ }^{74}$ and its possible lasting impact on victims. ${ }^{75}$ As such, apologies are not presented as a panacea for addressing the intricacies of HIA but are considered rather in terms of their latent capacity, when carefully constructed and delivered, to address some of the central relational complexities of the legacy of shame surrounding HIA.

Restorative discourses also recognise that shame can be 'managed' and used in a positive context. ${ }^{76}$ As Páez contends, the shame and sorrow expressed through apology are thought to support reparative tendencies. ${ }^{77}$ At the interpersonal level, the 'ritual' of apology and forgiveness is said to be an important means of managing shame for victims and perpetrators and of redirecting shame from the victim to the perpetrator. ${ }^{78}$ Collective apologies which are given on behalf of institutions (such as church and state), as well as wider society, may restore the dignity of victims ${ }^{79}$ as well as societal trust between communities and institutions. ${ }^{80}$ As Ahmed et al argue, 'to acknowledge shame and discharge it and to shame acts of injustice reintegratively are both important for preventing injustice and enabling restoration'. ${ }^{81}$ As discussed further, 'reintegrative shaming ${ }^{82}$ - via the censure of wrongdoing rather than wrongdoers - may be central to individual apologies and offender accountability in particular.

The literature also links the emotional framing of apology with the engagement of identity at a personal, social and institutional level. ${ }^{83}$ Shame is closely tied to the notion of ethical 'identity' and our perceived commitment to, and infringement of, a shared set of moral norms. ${ }^{84}$ As discussed above, 'shame' was integral to the functioning of the institutions and the culture that sustained them. Drawing on this broader framework, the paper argues that apology emerges as a focal mechanism for both expressing genuine remorse for wrongdoing and simultaneously displacing or managing shame for those constituencies affected by HIA - survivors, perpetrators, institutions as well as wider society. Indeed, it will be demonstrated that these themes of identity, connectivity and acceptance of responsibility lie at the heart of apology rhetoric and processes surrounding HIA at the individual and collective levels. That is, the present focus is on the role of apologies in repairing societal relationships, as well as those between survivors and perpetrators, and in addressing individual as well as collective harms stemming from HIA.

\footnotetext{
${ }^{70}$ See eg N Harris et al 'Emotional dynamics in restorative conferences' (2004) 8 Theoretical Criminology 191.

${ }^{71}$ G Kaufman The Psychology of Shame: Theory and Treatment of Shame-based Syndromes (Springer Publishing, 1996).

${ }^{72}$ Park, above n 29, at 355.

${ }^{73}$ Park, above n 29.

${ }^{74}$ The primary difference is that shame focuses on general evaluation of the self, whereas guilt focuses on a specific behaviour: see eg JP Tangney and RL Dearing Shame and Guilt (Guilford Press, 2002).

${ }^{75} \mathrm{C}$ Feiring and LS Taska 'The persistence of shame following sexual abuse: a longitudinal look at risk and recovery' (2005) 10 Child Maltreatment 337.

${ }^{76}$ See eg E Ahmed et al (eds) Shame Management Through Reintegration (Cambridge: Cambridge University Press, 2001).

${ }^{77} \mathrm{D}$ Páez 'Official or political apologies and improvement of intergroup relations: a neo-Durkheimian approach to official apologies as rituals’ (2010) 25 Revista de Psicología Social 101.

${ }^{78} \mathrm{H}$ Strang Repair or Revenge: Victims and Restorative Justice (Clarendon Press, 2002).

${ }^{79} \mathrm{~T}$ Govier and W Verwoerd 'The promise and pitfalls of apology' (2002) 3 Journal of Social Philosophy 67.

${ }^{80} \mathrm{P}$ de Greiff 'The role of apologies in national reconciliation processes: on making trustworthy institutions trusted' in $\mathrm{M}$ Gibney et al (eds) The Age of Apology (University of Pennsylvania Press, 2008).

${ }^{81}$ Above n 76, p 5.

${ }^{82}$ J Braithwaite Crime, Shame and Reintegration (Cambridge: Cambridge University Press, 1989) p 100.

${ }^{83}$ See eg M Augoustinos et al 'Apologizing for historical injustice: emotion, truth and identity in political discourse' (2011) 22 Discourse \& Society 507, who highlighted how Australian Prime Minister Rudd attempted to build support for the public apology to the 'Stolen Generations' by linking emotion to these various levels of identity.

${ }^{84} \mathrm{Ahmed}$ et al, above n 76.
} 


\section{Methodology}

Utilising the island of Ireland - NI and the RoI - as a case study, the aim of the wider study was to explore the way in which apologies have been constructed, delivered and received across three domains - paramilitary violence, HIA and the economic crisis. Within Ireland, there has been an ongoing proliferation of apologies from paramilitary, church, corporate and state leaders which remain subject to intense public scrutiny and debate. The fieldwork was informed by an extensive interdisciplinary literature review.

Over a five-year period (June 2016-November 2021), the research employed a triangulated methodology comprised of a bespoke archive of: public apologies across the three domains; a public survey (not drawn upon here); focus groups with the public and with victims; and in-depth semi-structured interviews with 'perpetrators', victims/survivors, legal professionals, local and national policy makers, civil society activists and other relevant stakeholders across NI and RoI. In light of potential risks to participants and researchers, a detailed ethical protocol was developed including access to support services.

Participants for the public focus groups $(n=14)$ were recruited via a market research company employing a stratified random sampling of adults, resident in either NI or RoI, and deliberately excluding those who self-identified as a victim. Stratification was based on age, gender, socio-economic group and location. For NI, as a society transitioning from ethno-national conflict, stratification was also based on religious background. Respondents were asked a series of questions relating to importance, awareness and adequacy of public apologies across the three domains.

The victim focus groups sought to capture the voices of victims/survivors, controlling for a range of demographics. While similar weightings informed the selection of participants for the semi-structured interviews, an initial purposive sampling strategy was employed to capture approximate numbers of 'perpetrators' and 'victims'. The aim was to seek the views of individuals who could speak to seminal apologies or who were involved in apology processes. There was an additional element of snowball sampling with some interviewees recommending others. The focus group and interview schedules were developed drawing on themes from the literature. Of the nine focus groups, only one was held with HIA victims due to ethical reasons, and additional individual interviews were conducted instead. A total of 68 interviews were conducted across all three sectors, 24 of which related specifically to HIA.

The focus groups and interviews were recorded and interviewees specified whether they wished to be anonymised. Both sets of data were transcribed and analysed thematically via a code book developed through NVivo. Consistent with most qualitative research, data analysis incorporated both inductive (where theory emerges from the data) and deductive (which explores whether the data is consistent with existing theories) approaches. ${ }^{85}$ Transcripts were initially blind-coded and agreed by the project team and themes were reviewed periodically. For present purposes, relevant major codes included accountability, acknowledgement, truth, emotions, leadership, national imagination, and choreography and performance.

\section{Towards a model of shame management}

Drawing on themes from the theoretical literature presented above and based on findings from the empirical data, this section examines the core complexities and latent potential of apology in addressing the 'shame' surrounding HIA at the individual, organisational and societal levels. It utilises the primary research to present a model of 'shame management' and, in so doing, argues that apology may assist in: the displacement of internalised shame or self-blame by victims; the acknowledgement of blame and expression of shame and remorse by wrongdoers; and the acceptance of responsibility by institutions of Church and State and wider society for their involvement in sustaining abusive regimes.

\footnotetext{
${ }^{85}$ See eg J Fereday and E Muir-Cochrane 'Demonstrating rigor using thematic analysis: a hybrid approach of inductive and deductive coding and theme development' (2006) 5 International Journal of Qualitative Methods 80.
} 
Thus, apology is presented as a potential means of facilitating: (a) truth for victims; (b) accountability of offenders; (c) leadership of institutions; and (d) the re-imagination of national identity. The first two elements speak to the reparative dimensions of apology at the interpersonal level, while the last two engage the institutional and societal dimensions.

\section{(a) Truth for victims}

The first aspect of apology as a means of shame management relates principally to identity and its potential to provide 'truth' or validation for victims by displacing their feelings of shame and selfblame surrounding their harmful experiences of HIA. In this respect, there were many examples of what interviewees described as 'mealy mouthed', ${ }^{86}$ 'hollow ${ }^{87}$ or 'shadow boxing' ${ }^{88}$ apologies offered by the Catholic Church for HIA which fail to address the legacy of a shameful past by refuting or minimising their involvement in abusive regimes. These sit broadly within Cohen's tri-partite framework of denial: ${ }^{89}$ (1) 'literal' denial - outright disavowal of the problem (eg 'abuses didn't happen'); (2) 'interpretative denial' - facts are given an alternative meaning and abuses justified by historical relativity (eg 'the culture of the time'); and (3) 'implicatory denial' - partial acknowledgement of abuses but scapegoating blame as an aberrational rather than systemic problem (eg 'a few bad apples'). Additionally, true acknowledgement may also be compromised by the use of obfuscatory or euphemistic language within apologies: 'hurt' or 'hardship' suffered rather than 'abuses' or 'harm'.

As noted at the outset, in the words of one survivor, 'many victims still blame themselves' for their experiences of HIA. ${ }^{90}$ As other scholars have noted, a fulsome apology, therefore, via a full and explicit acknowledgement of suffering, has the potential to validate victims' experiences, alleviate their sense of shame and restore their sense of personal identity and human dignity. ${ }^{91}$ Moreover, collective apologies also extend the truth-telling function to the wider community by educating the public on the nature and extent of wrongdoing and providing a more open account of the past. ${ }^{92}$ Therefore, apologies are not simply about justice; they are fundamentally about recognition and the overt removal of blame from victims.

Consistent with the literature on apology which establishes the centrality of acknowledgement, truth was cited as perhaps the number one priority of victims. Many of the survivors interviewed for the study framed an official apology as a basic need for recognition and an open, 'victim-centred acknowledgement ${ }^{93}$ that the abuse had happened and that they were in no way to blame. As one survivor explained, reflecting on an apology he had received: 'They didn't doubt whatsoever anything I'd said and that was the bit for me'. ${ }^{94}$ This viewpoint was shared by many survivors and some Church representatives:

Deep down in my heart... I would like somebody to stand in front of me and put their hand on my shoulder and say 'we apologise... because we believe you, we believe that there was abuse... [I] apologise for what you went through'... That's the kind of apology I would like. ${ }^{95}$

The central figure is the person who is abused and you have to say to them, you know, 'look, I believe you, it shouldn't have happened'... You can't but say, not just 'I'm sorry', but 'what

\footnotetext{
${ }^{86}$ Interview 8, Victims' Advocate, 21 February 2018.

${ }^{87}$ Interview 13, Survivor, 18 May 2018.

${ }^{88}$ Interview 3, Senior Social Worker, 14 December 2017.

${ }^{89} \mathrm{~S}$ Cohen States of Denial: Knowing About Atrocities and Suffering (Polity Press, 2001).

${ }^{90}$ Focus Group with HIA Survivors, Female 3, 13 November 2018.

${ }^{91}$ See eg M Murphy 'Apology, recognition, and reconciliation' (2011) 12 Human Rights Review 47.

${ }^{92}$ Weyeneth, above n 13 .

${ }^{93}$ Govier and Verwoerd, above n 79 , at 74 .

${ }^{94}$ Focus Group with HIA Survivors, Male 3, 13 November 2018.

${ }^{95}$ Focus Group with HIA Survivors, Female 1, 13 November 2018.
} 
happened to you is horrendous' and saying that is more important actually than the phrase 'I'm sorry'... This idea of recognition is more important... you have to say to people, 'this should never have happened and there are no excuses for it'. ${ }^{96}$

A survivor expressed the importance of truth in terms of the need to 'name the wrong' publicly where the apologiser must 'stand up, tell the whole world what you've done exactly wrong. You know, give us a blow-by-blow detailed account about, "Right, this is what happened". 97 This view was also shared by lawyers who represented victims: 'to make a true apology you have to recognise what was really done; ${ }^{98}$ and there needs to be 'absolute honesty about the wrongs.... it has to be encompassing all elements of the wrong committed'. ${ }^{99}$ Others explained the significance of an apology in terms of listening to the voice of victims and explicitly recognising their credibility, thereby removing the self-blame and shame historically attached to HIA: 'they just want to know it wasn't their fault ... that someone believes them and someone has heard them'; ${ }^{100}$ and 'it was about saying, "look, we now accept responsibility for this. You don't have to carry this anymore. This is not about you, it's about us"'. ${ }^{101}$

It was noted, however, that while an unreserved apology was seen as a hugely powerful thing for a victim to hear ... so few victims actually get that'. ${ }^{102}$ As a judge explained, for many adult HIA victims who did come forward previously as children and make an allegation of abuse 'the response almost invariably was, "that couldn't possibly have happened ... You, therefore are a liar". ${ }^{103}$ In such circumstances, therefore, a cathartic apology for victims offers a means of validating their abusive experience and of accepting the veracity of their story where 'their truthfulness has been recognised'. ${ }^{104}$

Govier and Verwoerd ${ }^{105}$ (2002) outline three elements of acknowledgement which are central to addressing the experiences of victims concerning HIA: (1) wrongdoing; (2) the moral status of victims; and (3) the legitimacy of victims' feelings of resentment and anger. While the interview narratives were collectively supportive of all three aspects, a fourth emerged relating to recognition of not only the fact of their abusive and shameful experiences, but the longer-term impact on victims. Significantly, a fuller acceptance and understanding of the harm caused for survivors was articulated not just in terms of the impact of physical and sexual abuse but neglect and emotional abuse 'at a basic level' and the intergenerational transmission of shame via the life-long consequences of the denial of opportunities for education. ${ }^{106}$ This core component of addressing the legacy of shame within a victim-centric apology was seen as being particularly pertinent for apologies offered by the Church:

An apology... is one way of saying what happened to you should not have happened..... This was a terrible abuse... and I regret the impact that this had on your life as a child and that it has had on your life down through the years. ${ }^{107}$

Acknowledgment of the reality of what had happened rather than just of hurt... We see how grave it was, how serious it is, and how much damage it did and we accept that we are now responsible legally for putting it right. ${ }^{108}$

\footnotetext{
${ }^{96}$ Interview 15, Senior Clergyman, 22 May 2018.

${ }^{97}$ Interview 17, Survivor, 24 September 2018.

${ }^{98}$ Interview 10, Lawyer, 26 April 2018.

${ }^{99}$ Interview 16, Lawyer, 8 August 2018.

${ }^{100}$ Interview 11, Victims' Advocate, 27 April 2018.

${ }^{101}$ Interview 7, Senior Government Official, 7 February 2018.

${ }^{102}$ Interview 11, Victims' Advocate, 27 April 2018.

${ }^{103}$ Interview 4, Judge, 9 January 2018.

${ }^{104}$ Ibid.

${ }^{105}$ Govier and Verwoerd, above n 79.

${ }^{106}$ Interview 3, Senior Social Worker, 14 December 2017.

${ }^{107}$ Interview 5, Senior Clergyman, 22 January 2018.

${ }^{108}$ Interview 20, Lawyer, 17 May 2019.
} 
For several interviewees, however, the crux of the issue for those apologies deemed inadequate or insincere was framed as relational disconnectedness: that 'they [the Church] don't get it', ${ }^{109}$ where there is a lack of 'true and genuine understanding of the damage that they did', ${ }^{110}$ or where those apologising 'really, really do not understand and don't want to understand and are in denial even of the huge impact the experience of abuse has had on the survivor'. ${ }^{111}$ As discussed below, while truth plays a crucial role in addressing a shameful past, acknowledgement alone does not imply the acceptance of responsibility for wrongdoing. In this sense, a genuine apology involves a common understanding of the injustice ${ }^{112}$ and constructing a narrative about the past which has been accepted by victims and perpetrators. Moreover, as discussed further in the final section, there is also a clear performative dimension to apologies in addressing shame for an abusive past which may supersede the verbal narrative of remorse.

\section{(b) Accountability of offenders}

The second dimension of apology as means of managing the legacy of shame surrounding HIA concerns the acknowledgement of blame and acceptance of responsibility by perpetrators. In tandem with the literature, as with truth, accountability emerges as a 'hallmark' of apology. ${ }^{113}$ Indeed, accountability is a fundamental notion within criminological, ${ }^{114}$ restorative ${ }^{115}$ and public administration discourses. ${ }^{116}$ Scholars point in particular to its instrumental or moral value ${ }^{117}$ as well as its utility in empowering victims and holding transgressors to account. ${ }^{118}$ In relation to HIA, the coalescence of the Irish State, the institutional Church, individual perpetrators and wider society in sustaining abusive regimes undoubtedly makes accountability much more complex and ultimately blurs direct lines of responsibility. The potential of apology in countering the past is considered here in terms of the accountability of individual offenders, with the other aspects examined in the sections below.

Scholars have established that an apology requires not only specific acknowledgement of wrongdoing but also the acceptance of responsibility by the wrongdoer, ${ }^{119}$ particularly in the case of serious wrongdoing. ${ }^{120}$ The initial acceptance of responsibility assists in the management of shame associated with past wrongs because it creates room for dialogue ${ }^{121}$ or common ground around what occurred. As noted above, the 'ritual' of apology and forgiveness is said to be an important means of managing shame for perpetrators as well as victims and of redirecting shame from the victim to the perpetrator. ${ }^{122}$ In this sense, apologies may also be rehabilitative for individual offenders as, by accepting responsibility for past wrongs, they can alleviate their own feelings of shame and guilt. ${ }^{123}$

\footnotetext{
${ }^{109}$ Interview 10, Lawyer, 20 April 2018.

${ }^{110}$ Ibid.

${ }^{111}$ Interview 8, Victims' Advocate, 21 February 2018.

${ }^{112} \mathrm{~J}$ Thompson 'Apology, justice, and respect: a critical defense of political apology' in M Gibney et al (eds) The Age of Apology (University of Pennsylvania Press, 2008).

${ }^{113}$ M Minow Between Vengeance and Forgiveness: Facing History After Genocide and Mass Violence (Beacon Press, 1998$)$ p 1.

${ }^{114}$ See eg W Schabas 'Criminology, accountability and international justice' in M Bosworth and C Hoyle (eds) What is Criminology (Oxford: Oxford University Press, 2013).

${ }^{115}$ See eg D Roche Accountability in Restorative Justice (Oxford: Oxford University Press, 2003).

${ }^{116}$ See eg N Bamford and P Leyland (eds) Accountability and the Constitution (Oxford: Oxford University Press, 2013).

${ }^{117}$ See eg J King 'The instrumental value of legal accountability' in Bamford and Leyland, ibid.

${ }^{118}$ See eg D O'Mahony and J Doak Reimagining Restorative Justice: Agency and Accountability in the Criminal Process (Bloomsbury, 2017).

${ }^{119}$ Tavuchis, above n 14, pp 18-19.

${ }^{120} \mathrm{M}$ Bennett and D Earwaker 'Victims' responses to apologies: the effects of offender responsibility and offense severity' (1994) 134 Journal of Social Psychology 457.

${ }^{121}$ T Govier 'What is acknowledgement and why is it important?' OSSA Conference Archive 1999, https://scholar.uwindsor. ca/ossaarchive/OSSA3/keynotes/1/, p 5 .

${ }^{122}$ Strang, above n 78 .

${ }^{123}$ Lazare, above n 17.
} 
However, turning to the empirical data, senior Church figures, while recognising the need for an apology to demonstrate the acceptance of organisational responsibility, were also mindful of the personal and institutional risks they faced in this regard:

It's not about, you know, me feeling better because I can blame somebody else... the importance of an apology is first of all to accept responsibility because the organisation is still there, but also to show that sense of humility and... where you can say, yeah, I got this wrong. The danger of course of this is that, in today's context, an apology can be used as a stick to beat you with and so the temptation is to not say any more than you have to. ${ }^{124}$

If the individual case moves into the public arena, even a private apology becomes public, you know. Sometimes people will ask for a written apology and you have to realise that that... could be used in other ways. ${ }^{125}$

These quotations also underline the potential cross-over between personal and public accountability or private and public apologies - which may act as a powerful disincentive to apologising for a shameful past. While it may be easier for organisations to issue a 'corporate apology' in an attempt to dissipate the ignominy surrounding individual cases of HIA, as discussed further, this also raises questions of distancing and the perceived legitimacy of 'third-party' apologies for historical wrongdoing.

On one level, 'accountability' may be deemed the other half of 'truth'. As Govier contends, by the explicit 'spelling out' ${ }^{126}$ of wrongdoing and acknowledgement of the degree of harm inflicted on the victim, offenders can accept personal responsibility for the past. However, the account-making function of apology, and in particular the value added by the acceptance of responsibility by the offender, can usefully be framed in terms of what Thompson calls the twin notions of 'moral' and 'remedial' responsibility. ${ }^{127}$ That is, while the former is backward-looking or 'causal' and focused on attributing blame, the latter is forward-looking and focused on 'outcomes' and corrective action. As a member of the public put it, reflecting on this shift from truth to accountability:

If it is not backed up by actions, it is worthless because that is how you test... sincerity. You know, an apology, it is worthless without them... there has to be a corresponding admission. ${ }^{128}$

Put simply, the potential of an apology to demonstrate offender accountability for the shame surrounding HIA is derived in appropriate follow-through mechanisms demonstrating a symbolic break with the injustices of the past.

For the participants in the present study, accountability for HIA could be demonstrated by public condemnation in a variety of ways. This included: 'resignation. Heads rolling'; ${ }^{129}$ and admitting 'what they are responsible for, [what] they need to own up to'. ${ }^{130}$ For many interviewees, including survivors, the public shaming of individual offenders for past wrongdoing was central to their understanding of an authentic apology: 'Something written up for the world to see and that their shame is exposed to the world'131; 'it's putting them to shame and letting the world know, even those who have never heard about it'; ${ }^{132}$ 'you know and all our hurt is down in record. Like, the people at fault on record, in public,

\footnotetext{
${ }^{124}$ Interview 5, Senior Clergyman, 22 January 2018.

${ }^{125}$ Interview 15, Senior Clergyman, 22 May 2018.

${ }^{126}$ Govier, above n 121, p 7.

${ }^{127}$ J Thompson 'Is political apology a sorry affair?' (2012) 21 Social \& Legal Studies 215 at 223.

${ }^{128}$ Public Focus Group, Fermanagh, Male 2, 23 January 2018.

${ }^{129}$ Public Focus Group, Dublin 3, Female 6, 21 November 2017.

${ }^{130}$ Public Focus Group, Fermanagh, Male 2, 23 January 2018.

${ }^{131}$ Interview 12, Survivor, 27 April 2018.

${ }^{132}$ Focus Group with HIA Survivors, Female 3, 12 November 2018.
} 
the way that we were done $[s i c]$. ${ }^{133}$ For others, however, accountability and genuine remorse were more appropriately evidenced at a collective rather than individual level by a public commitment to legal or policy reform. As a lawyer expressed it: 'the crux of a good apology is taking responsibility for the change that needs to happen'. ${ }^{134}$

The distinction between these two viewpoints can be usefully explained by reference to Braithwaite's seminal dichotomy of 'disintegrative' and 'reintegrative shaming. ${ }^{135}$ That is, by censuring 'evil deeds' rather than 'evil persons', ${ }^{136}$ apology can function as a means of invoking remorse and shame within a positive context of social disapproval. Viewed through this lens, therefore, it is the acceptance of remedial responsibility which shifts apology to the more constructive context of reintegrative shaming. As discussed in the next section, in the case of large-scale historical wrongdoing such as HIA, the capacity of apology to effectively countenance the past also turns on the acceptance of 'political', rather than personal, responsibility on behalf of a collective (that is the Irish State or the Catholic Church). ${ }^{137}$

\section{(c) Leadership of institutions}

The third contingent aspect of apology as a mode of shame management relates to the organisational dimension, involving the leadership of institutions and often engaging the multiple internal and external audiences affected by HIA. There are several notable examples of where the leadership of the Catholic Church has used the language of 'shame' within the semantic framing of apology. For example, following demands for his resignation over his handling of the Fr Brendan Smyth case decades before, Cardinal Sean Brady, then Archbishop of Armagh and Primate of All Ireland, offered the following public apology:

This week a painful episode from my own past has come before me ... I want to say to anyone who has been hurt by any failure on my part that I apologise to you with all my heart. I also apologise to all those who feel that I've let them down. Looking back, I am ashamed that I have not always upheld the values that I profess and believe in. ${ }^{138}$

While on one level, this apology appears to invoke his personal feelings of shame, the use of the passive voice ('those who feel that I've let them down) rather than active voice, dilutes the authenticity of the apology and its proximity to the apologiser. Similarly, Pope Francis, in one of his first public pleas for forgiveness around the institutional abuse crisis made the following apologetic statement:

I feel compelled to personally take on all the evil which some priests, quite a few in number, obviously not compared to the number of all the priests, to personally ask for forgiveness for the damage they have done for having sexually abused children. ${ }^{139}$

This also echoes the notion of 'implicatory denial' discussed above, whereby official responsibility for abuses is partially acknowledged but attributed to 'a few bad apples'. ${ }^{140}$ In both instances, the lack of leadership is illustrated by the use of strategic ambiguity or shame avoidance via the distancing from both personal 'blame' and wider institutional responsibility as part of 'crisis management'. ${ }^{141}$

\footnotetext{
${ }^{133}$ Ibid.

${ }^{134}$ Interview 20, Lawyer, 17 May 2019.

${ }^{135}$ Braithwaite, above $\mathrm{n} 82$.

${ }^{136}$ Ibid, p 101.

${ }^{137} \mathrm{H}$ Arendt 'Collective responsibility' in J Kohn (ed) Responsibility and Judgment (Schoken Books, 2003).

${ }^{138}$ Apology during mass on St Patrick's Day at Armagh Cathedral, 17 March 2010.

${ }^{139}$ Apology during meeting with a Catholic Children's Rights NGO at the Vatican, 11 April 2014.

${ }^{140}$ Cohen, above n 89.

${ }^{141}$ Hearit, above n 12; Barth, above n 52.
} 
There are myriad reasons why the institutional Church has thus far failed to self-shame and offer an adequate public apology, admitting the full extent of hierarchical knowledge of HIA and its cover-up. The literature, for example, relates these, inter alia, to 'goal displacement' and the need to manage reputational damage and limit potential legal and financial liability. ${ }^{142}$ Within the context of the present study, the reticence of the Catholic Church to offer fulsome and unequivocal public apologises for HIA was also related by several interviewees to its own internal constituency and specifically the motivation to avoid public shame and the suggestion of 'any dirtiness coming from their Church'. ${ }^{143}$ One interviewee explained by reference to Catholic religious tradition and the seal of the confessional:

We do have individual confession to protect the person and that goes back to the fact that confession in the early Church was public... and it was kind of out of sensitivity to human nature and shame and embarrassment of people that private confession evolved.... Nobody wants to be stood up and publicly humiliated. ${ }^{144}$

The unwillingness of the hierarchical Church to fully accept blame for HIA, but rather shift blame via what Dunne has labelled a 'defeasability' strategy ${ }^{145}$ - that it had lacked knowledge or control of the problem - has had the inevitable effect of undermining its authentic voice and the legitimacy of its moral leadership. The same priest explained:

[T] his is massive damage... to the mission of the church... its voice has been compromised, its authority... to speak on issues in society with an authentic voice has been compromised terribly and in fact written off.... On very important social questions, the Church's voice has been neutralised and almost removed. ${ }^{146}$

This demonstrates the internal transaction required on the part of the Church hierarchy as part of selfshaming - in taking public ownership for its historical wrongdoing via apology it may prompt societal reassessment of its spiritual identity and authority. In stark contrast, as the opening quotations exemplify, shame is deployed more readily as a central notion within many of the seminal and more expansive state apologies for HIA.

Within the context of state apologies, managing shame at the institutional level in the aftermath of widespread historical wrongdoing often necessitates connecting with multiple audiences. ${ }^{147}$ For example, both Enda Kenny and Michael Martin, in apologising on behalf of the Irish State for abuses within 'Magdalene laundries' and mother and baby institutions respectively, specifically link 'shame' to individual, collective and human identity ${ }^{148}$ - a word used multiple times within each of these apologies. ${ }^{149}$ Moreover, in acknowledging the women as 'blameless' and that this is 'a national shame' or a 'dark and shameful... part of our national history', they explicitly utilise apology as a means of accepting state and societal responsibility and of 'taking back' this shame. As discussed below, within this type of atonement rhetoric, leaders aspire to go beyond repairing an ignominious image towards

\footnotetext{
${ }^{142}$ Barth, ibid.

${ }^{143}$ Focus Group with HIA Survivors, Female 1, 12 November 2018.

${ }^{144}$ Interview 19, Priest, 12 November 2018.

${ }^{145}$ EA Dunne 'Clerical child sex abuse: the response of the Roman Catholic Church' (2004) 14 Journal of Community \& Applied Social Psychology 490 at 492.

${ }^{146}$ Interview 19, Priest, 12 November 2018.

${ }^{147}$ See also the Pastoral Letter to the Catholics of Ireland from Pope Benedict XVI (19 March 2010) which was addressed to multiple audiences - victims and their families, priests and religious who have abused, children and young people, priests and religious etc: see https://www.vatican.va/content/benedict-xvi/en/letters/2010/documents/hf_ben-xvi_let_20100319_churchireland.html.

${ }^{148}$ Augoustinos et al, above n 83.

${ }^{149}$ Above nn 1 and 2.
} 
creating a 'new image as a redeemed individual or nation'. ${ }^{150}$ This theme was also reflected in the interview narratives where many spoke laudably of Kenny's apology as the epitome of leadership, describing it as 'powerful', ${ }^{151}$ 'meaningful', 152 'impactful', ${ }^{153}$ 'intense' ${ }^{154}$ and 'explosive'. ${ }^{155}$ A survivor interviewee, for example, framed this apology as being emblematic of the State distancing itself from the Church and 'purging themselves of the Magdalen Laundry shame'. ${ }^{156}$

A significant sub-theme was the importance of personality and the ethical identity of individual leaders in determining their credibility to apologise on behalf of a collective. Following the literature on leadership and credibility, ${ }^{157}$ several members of the public associated leadership apologies with ethical capacity: 'has that person got clean hands themselves, otherwise how are they going to be capable?'158 Participants singled out Enda Kenny because he was seen as being 'trustworthy' and without blame since his character was untainted by previous political scandals:

I think Kenny in fairness has never had a stain against his character in any way, shape, or form. He was never embroiled in any of that, so you do take what he says with more gravitas because... there's no stain on his character, there's no question mark about him. So I think it all goes back to who apologises and the sincerity of the apology; the words could be exactly the same, but whoever's delivering it. ${ }^{159}$

This also resonates with the broader societal dimensions of apology as a form of redress in affirming shared moral values and restoring public trust between offending institutions and wider society. ${ }^{160}$

However, for some interviewees, the displays of leadership and the sincerity of some official apologies in meaningfully addressing the legacy of HIA were regarded more sceptically as having been severely undermined by the lack of appropriate follow-through by both Church and State:

I would say that saying sorry is the easiest word. Showing that you're sorry is a different thing.... In addition to apologising, we have put in, you know, systems which now make it less likely that it would happen. ${ }^{161}$

[T]o-date look what they have done... Enda Kenny, stood up in the Chamber of the Dáil, but quite frankly... it was just crocodile tears... because what they did after that, was just abominable... you can give an apology but if you are not going to back it up with some action well then it isn't worth saying... words come cheap. ${ }^{162}$

The notion of apology as providing a platform for tangible and meaningful redress was also strongly linked by members of the public to authority and having 'the power to make a change and difference (163 $^{-1}$ and 'their intention in fixing it'. ${ }^{164}$ This was seen as being particularly important where the apologiser

\footnotetext{
${ }^{150} \mathrm{~J}$ Koesten and RC Rowland 'The rhetoric of atonement' (2004) 55 Communication Studies 68 at 70; Benoit, above n 12.

${ }^{151}$ Interview 21, Survivor, 24 June 2019.

${ }^{152}$ Ibid.

${ }^{153}$ Interview 10, Lawyer, 20 April 2018.

${ }^{154}$ Interview 1, Nun, 22 November 2017.

${ }^{155}$ Ibid.

${ }^{156}$ Interview 12, Survivor, 27 April 18.

${ }^{157}$ See eg BZ Posner and JM Kouzes 'Relating leadership and credibility' (1988) 63 Psychological Reports 527; TE Basford et al 'Please accept my sincerest apologies: examining follower reactions to leader apology' (2014) 119 Journal of Business Ethics 99.

${ }^{158}$ Public Focus Group, Newry 2, Female 4, 28 May 2018.

${ }^{159}$ Public Focus Group, Dublin 1, Male 5, 13 November 2017.

${ }^{160}$ De Greiff, above n 80 .

${ }^{161}$ Interview 15, Senior clergyman, 22 May 2018.

${ }^{162}$ Interview 22, Survivor, 24 June 2018.

${ }^{163}$ Public Focus Group, Dublin 1, Male 6, 13 November 2017.

${ }^{164}$ Public Focus Group, Dublin 1, Male 8, 13 November 2017.
} 
was apologising on behalf of someone else or 'hasn't been in the direct line of how it happened. ${ }^{165}$ This theme also echoes the notion of apologies as a 'speech act'. ${ }^{166}$ As a victims' advocate explained, in order to be effective as a form of shame management, official apologies need to be accompanied by purposive action, so that apologisers are not seen as 'just going through the motions. ${ }^{167}$

Taking both viewpoints from the empirical data together, therefore, for official apologies delivered by leaders, the perceived potential of apology to meaningfully address the legacy of the past stems from consistency of message, derived in either the previous good character and behaviours of the apologiser or the delivery of appropriate follow-through mechanisms. As discussed in the final section, in order to be effective as a form of shame management the apologiser must also have the perceived imprimatur to apologise on behalf of a collective. The potential of an official or 'leader' apology to address the legacy of the past also invokes questions of national identity and how society views itself and the darker chapters of its history. As one interviewee put it: 'public acknowledgement goes beyond a leader.... It has to resonate with all the citizens of the country'. ${ }^{168}$

\section{(d) Re-imagination of national identity}

The fourth element of apology as a means of shame management, and a major theme emerging from the study, relates to the wider societal dimensions. In this respect, state apologies for collective wrongdoing also raise questions of national identity and tap into what Celermajer and Kidman refer to as 'the emotional fabric of a nation'. ${ }^{169}$ The collective nature of the harms concerning HIA, and in particular the role of wider Irish society in sustaining abusive regimes as outlined above, helped to encourage cultural silence and complicity for decades. In this sense, a state or organisational apology may help to alleviate some of the collective as well as individual shame citizens may feel for 'turning a blind eye' or allowing their family members to end up in such institutions.

The work of Benedict Anderson highlights that nations are 'imagined communities' which promote social cohesion and common purpose between members. ${ }^{170}$ This imagined national identity stems from entrenched common narratives shaped by a complex interplay of factors including the territorialisation of religious faiths and shared collective memories. As noted above, there is often a stark disparity between an institution's or nation's benevolent self-image as morally pure or progressive and the shameful legacy of an abusive past. However, the imagined nature of national identity also denotes its malleability, which means that it can be renegotiated or re-imagined. ${ }^{171}$ As scholars have contended, the consequences of effective political apologies are in terms of renegotiating the legal, political and affective dimensions of citizenship', ${ }^{172}$ where 'the status of victims' is redefined 'as objects of ethical respect. ${ }^{173}$ Within this new moral community, the majority of citizens reconnect with the plight of the victimised minority and wrongdoing is no longer tolerated or ignored.

For example, Kenny ends his seminal 2013 apology with reference to a radically transformed Ireland in the present and future based on a new shared normative identity:

Today we live in a very different Ireland with a very different consciousness awareness - an Ireland where we have more compassion, empathy, insight and heart... we are trying to make

\footnotetext{
${ }^{165}$ Public Focus Group, Dublin 1, Male 6, 13 November 2017.

${ }^{166}$ Austin, above n 44.

${ }^{167}$ Interview 8, Victims' Advocate, 21 February 2018.

${ }^{168}$ Ibid.

${ }^{169}$ D Celermajer and J Kidman 'Embedding the apology in the nation's identity' (2012) 121 The Journal of the Polynesian Society 219.

${ }^{170}$ Anderson, above n 39.

${ }^{171}$ E Barkan and A Karn (eds) Taking Wrongs Seriously: Apologies and Reconciliation (Stanford University Press, 2006).

${ }^{172} \mathrm{M}$ Thaler 'Just pretending: political apologies for historical injustice and vice's tribute to virtue' (2012) 15 Critical Review of International Social and Political Philosophy 259.

${ }^{173} \mathrm{M}$ Mihai 'When the state says "sorry”: state apologies as exemplary political judgments' (2013) 2 Journal of Political Philosophy 200 at 206.
} 
sure we quarantine such abject behaviour in our past and eradicate it from Ireland's present and Ireland's future. ${ }^{174}$

This apology, therefore, was used as a bridge between historical and contemporary national identity to reconcile Irish citizens with their role in past injustices and to demonstrate a shared commitment to a new inclusive cultural narrative which is more progressive and benign. A victims' advocate explained these dual dimensions of apology, highlighting the notions of transgenerational, collective responsibility for historical wrongdoing while moving on from the legacy of an abusive past:

In terms of the public apologies... it is a recognition that as a society, we were all complicit in what happened to the children in the institutions... We were all turned into passive bystanders because of the hold the Catholic Church had on this country at the time.... So, it is really important in terms of reflecting on the type of society we are and the way we want to treat our children, that we all take responsibility for the type of society that existed then. The public apologies are part of a step to acknowledging that truth and it is a declaration that we were just not good enough and we need to find better ways to move forward. ${ }^{175}$

This viewpoint, relating to society more broadly, also resonates with literature on apologies in the aftermath of war or mass atrocities in terms of Irish society coming to terms with 'its "darker" chapters' whilst also 'inoculat[ing] itself against repeating the mistakes of a "bad past". ${ }^{176}$ However, the theme of national imagination emerging from the primary research has resonance for not only Irish citizens more broadly but also those directly affected by HIA.

In this vein, a minority of survivor interviewees professed that they had remained within the Catholic Church and were able to separate out their faith in the institutional Church from their feelings towards individual perpetrators or senior religious figures. This is also reinforced, for example, by newspaper reports demonstrating increased mass attendance within Ireland in the aftermath of the Ryan and Murphy Commission reports. ${ }^{177}$ Many other interviewees, however, particularly survivors and their advocates, expressed shame at their Catholic identity: 'I am really ashamed to be a Catholic and call myself Catholic knowing our Church supressed it and let it continue on for generations. ${ }^{178}$ Many survivors left Ireland upon leaving the institutions, emigrating to England, the United States and Australia. ${ }^{179}$ For them, leaving Ireland represented a symbolic and literal break with their 'Irishness' and their abusive past. A lawyer who had represented victims recounted:

One of the witnesses... had moved to England, changed his name by Deed Poll, had invented an entire new persona, eradicated every single trace of his Irishness, had nothing but contempt for Ireland, the Irish and everything to do with it and changed religion. Even though I don't believe he was particularly religious, I think he just did it as another further step to move himself as far as he could away from the Catholic Church. ${ }^{180}$

Similarly, the same victims' advocate cited above reflected on the Kenny apology as a means of removing any vestiges of national shame and restoring imagined Irishness to survivors of HIA:

\footnotetext{
${ }^{174}$ Above $\mathrm{n} 1$.

${ }^{175}$ Interview 8, Victims' Advocate, 21 February 2018.

${ }^{176} \mathrm{JW}$ Yamazaki Japanese Apologies after World War II (Routledge, 2005) p 128.

${ }^{177}$ See Commission to Inquire into Child Abuse and Commission of Investigation Reports, above nn 41 and 53; see P

McGarry 'Mass attendance in Ireland is up', Irish Times, 11 November 2009.

${ }^{178}$ Interview 13, Survivor, 14 May 2018.

${ }^{179}$ See eg B Fahy Freedom of Angels: Childhood in Goldenbridge Orphanage (O’Brien Press, 1999).

${ }^{180}$ Interview 10, Lawyer, 26 April 2018.
} 
When Enda Kenny apologised and accused the Vatican of being involved in cover ups, we had a huge response here from people, not just institutional abuse but also victims of clerical abuse. I can remember one man ringing up the next morning and saying that for the first time, he felt like a real citizen of Ireland. So, that was very, very important.... It is an acknowledgement, that as a citizen of this country they have been harmed and that the State has been complicit in that. ${ }^{181}$

In fact, an apology from the Irish state, rather than the Catholic Church who ran the institutions, was seen by several interviewees as being more important to victims. This was generally attributed to two factors: hearing the voice of victims - 'it was an acknowledgement ... that the state was listening to them'; ${ }^{182}$ and the spectacle of legalism - 'that is where our laws are made ... if the state or politicians makes the legal sort of side of it, that could all filter through to other areas as well'. ${ }^{183}$

In addition, the theme of apology and imagined community is closely intertwined with the notions of truth and memorialisation as a means of helping people re-establish their personal or social identities. For example, in relation to truth and identity, at the time of writing, an enduring issue for victims/survivors, particularly those who had been in 'Magdalen laundries' or mother and baby institutions where children were adopted, is the right of access to their records and their own personal truth narratives. ${ }^{184}$ A survivor interviewee who had advocated on behalf of other survivors explained:

This was an issue I wanted dealt with, people had a right to their identity... the parents had rights. They were citizens of the State. But, that's exactly the point, we weren't. ${ }^{185}$

As regards memorialisation and identity, the conservation of institutions stands as a permanent memorial to human suffering and a tangible reminder to current and future generations of citizens of a national shame, the proximity of the abuses and of wrongs perpetrated in their name. A survivor recommended 'keep[ing] every single one of them institutions because I think it's part of our heritage and our history;' and suggested introducing the history of institutions in Ireland into the school curriculum as a way of preserving 'living history'. ${ }^{186}$ Other survivors, however, do not want to be confronted with a painful reminder of their and the nation's shameful past and have actively sought 'de-memorialisation' in the form of the destruction of now abandoned institutions or the removal of gravestones of known perpetrators from local landscapes. ${ }^{187}$ This also conveys the tension between the backward- and forward-looking dimensions of apology as symbolic reparation which must simultaneously stand as acknowledgement of past abuses as well as an ongoing commitment to societal change.

\section{Conclusion: the performance of shame}

There is broad consensus within the literature that meaningfully engaging with the complex rubric of the past is unlikely to emerge from apologies on their own. Within this context, official apologies usually need to be offered in conjunction with a tranche of justice mechanisms such as truth-telling, prosecutions, other forms of tangible reparations and institutional reform. ${ }^{188}$ This paper, however, has

\footnotetext{
${ }^{181}$ Interview 8, Victims' Advocate, 21 February 2018.

${ }^{182}$ Interview 3, Senior Social Worker, 14 December 2017.

${ }^{183}$ Public Focus Group, Derry 2, Participant E, 29 January 2018.

${ }^{184}$ Within the context of historical adoptions from within such Catholic-run state institutions, birth and adoption records are often missing or incomplete, or information has been deliberately withheld. See the Civil Registration (Right of Adoptees to Information) (Amendment) Bill 2021 in the Republic of Ireland which seeks to remove some of the barriers to accessing birth records.

${ }^{185}$ Interview 21, Victim/Survivor, 24 June 2019.

${ }^{186}$ Interview 17, Victim/Survivor, 24 September 2018.

${ }^{187}$ For example, the removal of a large headstone marking the grave of Fr Malachy Finnegan was part of an out-of-court settlement package - including a letter of apology/acknowledgment and compensation - to a victim of historical clerical sexual abuse in NI: see https://krw-law.ie/dromore/ (October 2017).

${ }^{188}$ See eg in the TJ context: Teitel, above n 57.
} 
envisaged a broader and more central role for apology within justice processes where it has been presented as a means of providing truth for victims; accountability of offenders; leadership of institutions; and the re-imagination of national identity. In particular, this analysis has underlined the significance and complexities of the relational dimensions of apology in addressing the legacy of shame surrounding HIA at the interpersonal, institutional and societal levels and therein the central themes of identity, connectedness and responsibility.

In addition to content, however, the transformative potential of apology in managing shame in the aftermath of HIA at the personal, institutional and societal levels is contingent on a final dimension. This relates to apology as a means of 'performative redress' ${ }^{189}$ and how the emotional spectacle of apology is optimally choreographed and delivered, particularly in public settings. The literature establishes the ritualistic or ceremonial aspects of political apologies as 'art ${ }^{\text {'190 }}$ or 'stage events ${ }^{\text {'191 }}$ as part of 'gestural politics'. ${ }^{192}$ This includes a range of variables such as the choice of setting, timing and the status of the speaker. ${ }^{193}$ It is these performative aspects which augment the value of apology as a form of symbolic reparation. Put simply, the perceived authenticity of an apology, and its relational capacity to manage shame in the aftermath of HIA, ultimately depends on how it is delivered as much as the actual words themselves. What Scheff, ${ }^{194}$ in the restorative justice context, frames as 'emotional reparation', and in particular redirecting feelings of 'shame' towards empathy, can often supersede the verbal discourse of remorse.

Within this broader context, a novel element of apologies as performative redress emerging from the fieldwork, and which does not feature heavily in the literature, ${ }^{195}$ was the necessary display of emotion and visible remorse on the part of the apologiser. The multiple audiences of public apologies for HIA - victims/survivors, members of offending institutions as well as the general public - articulated the need for such apologies to be 'heartfelt' or 'from the heart'. Both victims and representatives of apologising institutions, tended to judge the sincerity of apology by the degree of emotion and shame expressed by the apologiser: 'there's an honesty in it'; ${ }^{196}$ '[it] should have feeling, it should be humane'; ${ }^{197}$ 'A true apology is one with emotion in it'; ${ }^{198}$ 'an apology is at least partly an act of solidarity, a way of saying I am moved by what you have experienced'. ${ }^{199}$ A victims' advocate explained in terms of the fundamental need for emotional engagement at a human level:

Victims have said to me very strongly that what I want to feel is that what happened to me matters to the institution... I want to feel it's real... It is not a matter just of words, it is a matter of expressing emotion... It is human relationships, and ultimately, an apology is only meaningful if it is delivered within the context of that human relationship in a way that is sincere. ${ }^{200}$

For example, the apology by former Taoiseach Bertie Ahern, referenced above, ${ }^{201}$ was described by a survivor as being 'made with feeling. You could tell that they resonated with the suffering of people to whom they were apologising... It was very well meant... I was very touched by it'. ${ }^{202}$ Similarly, the apology by Pope Francis in Croke Park on 26 August 2018 during his visit to Ireland was described by

\footnotetext{
${ }^{189} \mathrm{~J}$ Borneman 'Public apologies as performative redress' (2005) 25 SAIS Review of International Affairs 53.

${ }^{190}$ DP Boyd 'Art and artifice in public apologies' (2011) 104 Journal of Business Ethics 299.

${ }^{191} \mathrm{~S}$ Cels 'Interpreting political apologies: the neglected role of performance' (2015) 36 Political Psychology 351 at 355.

${ }^{192}$ Cunningham, above $\mathrm{n} 11$, at 288 .

${ }^{193}$ See eg Wilson and Bleiker, above n 46.

${ }^{194}$ TJ Scheff 'Community conferences: shame and anger in therapeutic jurisprudence' (1998) 67 Revista Juridica (UPR) 9.

${ }^{195}$ See exceptionally Govier and Verwoerd, above n 79.

${ }^{196}$ Interview 15, Senior Clergyman, 22 May 2018.

${ }^{197}$ Interview 14, Survivor, 14 May 2018.

${ }^{198}$ Focus Group with HIA Survivors, Female 2, 12 November 18.

${ }^{199}$ Interview 5, Senior Clergyman, 22 January 2018.

${ }^{200}$ Interview 2, Victims' advocate, 28 November 2017.

${ }^{201}$ Above $\mathrm{n} 9$.

${ }^{202}$ Interview 21, Survivor, 24 June 2019.
} 
a Priest as 'very moving... it meant a lot'. ${ }^{203}$ In relation to the Kenny apology in particular, the fact that 'he was quite emotionally in $\mathrm{it}^{204}$ was perceived as being fundamental to many of the constituent elements of shame management set out above - namely the accountability of offenders, the leadership of institutions and the re-imagination of national identity:

But bringing it all back to first bases, talking about the apology... I thought Enda Kenny's speech to the Dail that he gave back in 2013 with respect to the Church and their treatment of people... I thought it was moving and that's what I wanted as a citizen of this country. ${ }^{205}$

On the other hand, for many participants, particularly members of the public, such apologies, typically offered decades later for historical wrongdoing by their predecessors, were regarded in a more cynical fashion as 'empty symbolism,206 and described as 'architected', 207 'tokenistic'208 and 'third-party', 209 which 'I don't think hold any weight'. ${ }^{210}$

For others, however, including some survivors, the outward display of emotion by contemporary church or state leaders within what have been deemed 'inter-temporal or historical apologies ${ }^{211}$ provided a personal and visual connective to collective historical wrongdoing. A survivor posed this issue of remote responsibility by so-called 'surrogate offenders' ${ }^{212}$ in rhetorical terms:

They can't apologise for, as I say, history, because it wasn't them who did what they did.... you could have one person apologising for everybody and then it means nothing. So the problem is there's so many people - how to do it? That's the difficulty isn't it? ${ }^{213}$

Therefore, there is a clear human dimension to shame management which depends on the emotional engagement of the parties. As Coicaud and Jönsson argue, 'For the same reason that dehumanization is the most powerful tool of war, humanization is the most powerful tool of reconciliation'. ${ }^{214}$ According to this view, apologies, while they cannot undo past wrongdoing, are an attempt at humanisation - they can redress the 'moral vulnerability' of victims ${ }^{215}$ by holding individual perpetrators and institutions to account and correcting the public record about the past. More specifically, the significance of an emotional apology and the emotive expression of regret is that, to victims and victimised communities, it is also strongly indicative of proximity and the tangible ownership of responsibility for a shameful past in the present by offenders and offending institutions in particular.

The study has highlighted the importance of both the relational and performative aspects of apology as a vehicle for shame management in the aftermath of HIA within the context of the island of Ireland. The extensive nature of the empirical work drawn upon here - with findings triangulated across victim and public focus groups as well as stakeholder interviews - would tend to affirm the strength and validity of the conclusions. On one level, although 'shame' is an integral and residual

\footnotetext{
${ }^{203}$ Interview 19, Priest, 12 November 2018.

${ }^{204}$ Public Focus Group, Dublin 1, Male 1, 13 November 2017.

${ }^{205}$ Interview 10, Lawyer, 20 April 2018.

${ }^{206}$ TL Zutlevics 'Reconciliation, responsibility, and apology' (2002) 16 Public Affairs Quarterly 63.

${ }^{207}$ Public Focus Group, Dublin 1, Male 9, 13 November 2017.

${ }^{208}$ Interview 7, Senior Government Official, 7 February 2018.

${ }^{209}$ Interview 8, Victims' Advocate, 21 February 2018.

${ }^{210}$ Public Focus Group, Newry 1, Female 3, 22 January 2018.

${ }^{211}$ Celermajer, above n 46, p 15.

${ }^{212} \mathrm{~T}$ Gavrielides 'Clergy child sexual abuse and the restorative justice dialogue' (2012) 55 Journal of Church and State 617 at $625-626$.

${ }^{213}$ HIA survivors focus group, Male 3, 13 November 2018.

${ }^{214} \mathrm{~J}$-M Coicaud and J Jönsson 'Elements of a road map for a politics of apology' in M Gibney et al (eds) The Age of Apology (University of Pennsylvania Press, 2008) p 90.

${ }^{215} \mathrm{MU}$ Walker 'Moral vulnerability and the task of reparations' in C MacKenzie et al (eds) Vulnerability: New Essays in Ethics and Feminist Philosophy (Oxford: Oxford University Press, 2014).
} 
aspect of sexual abuse more broadly, ${ }^{216}$ the paper has highlighted the particular and acute nature of shame within the historical context of Ireland. As such, the findings also suggest the need for additional empirical research in other societies or religious denominations affected by historical institutional abuses. At the same time, however, given the centrality of apology to contemporary official responses to historical injustices more broadly, the conclusions are also transferable to other contexts of dealing with the legacy of the past.

In this regard, the cogency of official apologies in providing redress for a shameful past can usefully be appraised in philosophical terms within Aristotle's 'modes of persuasion' ${ }^{217}$ - they must have logical, ethical and emotional appeal. That is, the actual words themselves (logos) are undoubtedly important in providing truth and acknowledgement for victims and demonstrating the acceptance of responsibility and accountability by offenders. However, the ethical character and credibility of the apologiser (ethos), typically a leading figure within the organisation, are also fundamental to repairing the institution's self and public image and engaging the multiple internal and external constituencies affected by HIA. Finally, an appeal to audience emotions (pathos) is pivotal to garnering public support for victims and the envisaging of a new world order where a firm collective commitment is offered to move on and learn from the legacy of the past.

\footnotetext{
${ }^{216}$ Feiring and Taska, above $\mathrm{n} 75$.

${ }^{217} \mathrm{C}$ Rapp 'Aristotle's rhetoric' in EN Zalta (ed) The Stanford Encyclopaedia of Philosophy (Stanford University Press, 2010).
}

Cite this article: McAlinden A-M (2022). Apologies as 'shame management': the politics of remorse in the aftermath of historical institutional abuse. Legal Studies 42, 137-158. https://doi.org/10.1017/lst.2021.39 